\begin{tabular}{|c|c|}
\hline $\begin{array}{l}\text { Journal of } \\
\text { entReview }\end{array}$ & $\begin{array}{l}\text { Publiser } \\
\text { Graduate Program Universitas Galuh } \\
\text { Master Manajemen Studies Program } \\
\text { @ } 2017\end{array}$ \\
\hline
\end{tabular}

\title{
PENGARUH PENDAPATAN ASLI DAERAH (PAD), DANA ALOKASI UMUM (DAU) DAN SISA LEBIH PEMBIAYAAN ANGGARAN (SiLPA) TERHADAP ANGGARAN BELANJA MODAL PADA PEMERINTAH KOTA BANJAR
}

\author{
Engkos Kosim ${ }^{1}$ \\ ${ }^{1}$ Program Studi Magister Manajemen Program Pascasarjana Universitas Galuh Ciamis \\ e-mail : pascaunigal@gmail.com
}

Article History :
Recieved 6 December 2016
Recieved in revished form
22 December 2016
Acepted 5 Januari 2017
Available offline 20 Januari 2017
Available online 20 Januari 2017

Language Transcript :

Indonesia

Key Words :

$P A D$

$D A U$

SiLPA

Belanja Modal

\begin{abstract}
Penelitian ini dilakukan karena hasil observasi penulis bahwa konstribusi Anggaran Pendapatan Asli Daerah (PAD) pada Pemerintah Kota Banjar masih relatif kecil, tingkat ketergantungan fiskal Pemerintah Kota Banjar terhadap Dana Alokasi Umum (DAU) masih relatif tinggi, Pemerintah Kota Banjar masih belum optimal untuk mengelola Sisa Lebih Pembiayaan Anggaran (SiLPA), Anggaran Belanja Modal pada Pemerintah Kota Banjar Dari tahun 2007 sampai dengan tahun 2014 masih relatif kecil. Tujuan penelitian ini adalah untuk mempelajari, mengetahui, dan menganalisis pengaruh Pendapatan Asli Daerah (PAD), Dana Alokasi Umum (DAU) dan Sisa Lebih Pembiayaan Anggaran (SiLPA) terhadap Anggaran Belanja Modal. Sedangkan metode yang digunakan dalam penelitian ini adalah metode yang digunakan dalam penelitian ini adalah ex post facto dengan pendekatan kuantitatif, sedangkan teknis analisis data, yaitu statistik deskriptif Analisis dan Statistik Induktif (Inferensial) dengan menggunakan analisis jalur (Path Analysis). Hasil penelitian menginformasikan bahwa (1). Pendapatan Asli Daerah (PAD) berpengaruh terhadap anggaran belanja modal. Artinya jika Pendapatan Asli Daerah (PAD) meningkat, maka anggaran belanja modal akan meningkat pula. (2). Dana Alokasi Umum (DAU) berpengaruh terhadap Anggaran Belanja Modal. Artinya jika Dana Alokasi Umum (DAU) meningkat, maka Anggaran Belanja Modal akan meningkat pula. (3). Sisa Lebih Pembiayaan Anggaran (SiLPA)berpengaruh terhadap Anggaran Belanja Modal. Artinya jika Sisa Lebih Pembiayaan Anggaran (SiLPA) meningkat, maka Anggaran Belanja Modal akan meningkat pula. (4). Pendapatan Asli Daerah (PAD), Dana Alokasi Umum (DAU) dan Sisa Lebih Pembiayaan Anggaran (SiLPA) berpengaruh terhadap Anggaran Belanja Modal. Artinya jika Pendapatan Asli Daerah (PAD), Dana Alokasi Umum (DAU) dan Sisa Lebih Pembiayaan Anggaran (SiLPA) meningkat, maka Anggaran Belanja Modal akan meningkat pula.
\end{abstract}

\section{PENDAHULUAN}

Dalam rangka melaksanakan amanat otonomi terutama perihal peningkatan kemandirian fiskal, Pemerintah Kota Banjar terus berusaha mengoptimalkan pengelolaan Pendapatan Asli Daerah
(PAD). Pendapatan Asli Daerah (PAD) Pemerintah Kota Banjar masih didominasi pendapatan dari retribusi pelayanan kesehatan terutama dari Badan Layanan Umum Daerah Rumah Sakit Kota Banjar 
dan Pendapatan Pajak Bumi dan Bangunan Perkotaan dan Perdesaan (PBBP2).

Anggaran Pendapatan Asli Daerah (PAD) Pemerintah Kota Banjar dari tahun 2007 sampai dengan tahun 2014 menunjukkan trend meningkat. Pada tahun 2014 Anggaran Pendapatan Asli Daerah (PAD) sebesar Rp. 103.638.432.277,00 mengalami peningkatan sebesar Rp. 43.417.912.144,00 atau $72,10 \%$ dari Anggaran Pendapatan Asli Daerah (PAD) tahun 2013 sebesar Rp. 60.220.520.133,00, kenaikan pada tahun 2014 merupakan kenaikan terbesar selama kurun waktu 2007 sampai dengan 2014. Rata-rata Anggaran Pendapatan Asli Daerah (PAD) dari tahun 2007 sampai dengan tahun 2014 sebesar Rp. 45.604.817.314,37 dan rata-rata kenaikan Anggaran Pendapatan Asli Daerah (PAD) sebesar Rp. 10.086.694.620,25 atau $22,12 \%$.

Kontribusi Anggaran Pendapatan Asli Daerah (PAD) dari tahun 2007 sampai dengan tahun 2014 rata-rata sebesar Rp. 45.604.817.314,37 atau 9,75\% terhadap rata-rata Total Anggaran Pendapatan pada Anggaran Pendapatan Dan Belanja Daerah (APBD) sebesar Rp. 467.534.805.701,88. Kontribusi terbesar Anggaran Pendapatan Asli Daerah (PAD) terhadap Total Anggaran Pendapatan Daerah terjadi pada tahun 2014, Pada tahun tersebut Anggaran Pendapatan Asli Daerah (PAD) adalah sebesar Rp. 103.638.432.227,00 atau $14.96 \%$ dari Total Anggaran Pendapatan Daerah sebesar Rp. 692.774.045.143,00. Dari Data tersebut menunjukkan bahwa, meskipun Pendapatan Asli Daerah Pemerintah Kota Banjar terus meningkat dari tahun 2007 sampai dengan 2014, akan tetapi jika dilihat dari konstribusi Anggaran Pendapatan Asli Daerah (PAD) terhadap Total Pendapatan Daerah masih menunjukkan tingkat kemandirian fiskal Pemerintah Kota Banjar masih belum optimal dan hal ini merupakan permasalahan yang sama dialami sebagian besar Daerah Otonom di Indonesia.

Anggaran Dana Alokasi Umum (DAU) pada Pemerintah Kota Banjar dari tahun 2007 sampai dengan tahun 2014 cenderung fluktuatif. Pada tahun 2012 Anggaran Dana Alokasi Umum (DAU) sebesar Rp. 281.851.254.000,00 mengalami kenaikan sebesar Rp. 45.988.688.000,00 atau 19,50\% dari Anggaran Dana Alokasi Umum (DAU) tahun 2011 sebesar Rp. 235.862.566.000,00. Kenaikan tersebut merupakan kenaikan terbesar dalam kurun waktu 2007 sampai dengan 2014. Pada tahun 2008 Anggaran Dana Alokasi Umum sebesar Rp. 191.153.330.000,00 mengalami penurunan sebesar Rp. 82.078.670.000,00 atau $30,04 \%$ dari Anggaran Dana Alokasi Umum (DAU) tahun 2007 sebesar Rp. 273.232.000.000,00, penurunan pada tahun 2008 merupakan penurunan yang paling besar selama kurun waktu 2007 sampai dengan 2014.

Rata-rata kontribusi Anggaran Dana Alokasi Umum (DAU) terhadap Anggaran Pendapatan Pemerintah Kota Banjar dari tahun 2007 sampai dengan tahun 2014 sebesar Rp. 258.560.390.375,00 atau 55,30\%. Pada tahun 2007 Anggaran Dana Alokasi Umum (DAU) sebesar Rp. 273.232.000.000,00 atau 73,02\% dari total Anggaran Pendapatan tahun yang sama sebesar Rp. 374.184.738.141,00 yang merupakan Anggaran Dana Alokasi Umum (DAU) tertinggi dalam kurun waktu 2007 sampai dengan 2014. Dari data tersebut menunjukkan bahwa tingkat ketergantungan fiskal Pemerintah Kota Banjar terhadap Dana Alokasi Umum (DAU) masih relatif tinggi.

Pembiayaan merupakan sumber penerimaan lain yang dapat digunakan oleh Pemerintah Daerah untuk mendanai penyelenggaraan Pemerintah Daerah, selain Pendapatan Asli Daerah (PAD), Pendapatan Transfer dan 
journal of managementReview

ISSN-P : 2580-4138 ISSN-E 2579-812X http://jurnal.unigal.ac.id/index.php/managementreview Volume 1 Number 1 Page (13-23)

Lain-Lain Pendapatan Asli Daerah.

Penerimaan Pembiayaan dapat menjadi alternatif bagi Pemerintah Daerah untuk meningkatkan kemampuan fiskal (fiscal capacity) sehingga memiliki keleluasaan dana untuk mengalokasikan pada anggaran belanja modal. Menurut Peraturan Pemerintah Nomor 58 Tahun 2005 Pasal 1 Angka 31 menyatakan bahwa "Sisa Lebih Perhitung Anggaran yang selanjutnya disingkat SiLPA adalah selisih lebih realisasi penerimaan dan pengeluaran anggaran selama satu periode anggaran".

Sisa Lebih Pembiayaan Anggaran (SiLPA) pada Pemerintah Kota Banjar dari tahun 2007 sampai dengan tahun 2014 cenderung fluktuatif, Pada tahun 2013 SiLPA sebesar Rp. 108.294.340.684,00 mengalami kenaikan sebesar Rp. 43.784.263.282,00 atau 67,87\% dari SiLPA tahun 2012 sebesar Rp. 64.510.077.402,00 yang merupakan Kenaikan Terbesar SiLPA dalam kurun waktu 2007 sampai dengan 2014. Pada tahun 2014 SiLPA sebesar Rp. 82.880.966.092,00, mengalami penurunan sebesar Rp. 25.413.374.592,00 atau 23,47\% dari SiLPA tahun 2013 sebesar Rp. 108.294.340.684,00, penurunan tersebut merupakan Penurunan Terbesar SiLPA dalam kurun waktu 2007 sampai dengan 2014. Rata-rata SiLPA dari tahun 2007 sampai dengan tahun 2014 adalah sebesar Rp. 70.068.312.820,06 atau 13,03\%.

Rata-rata kontribusi SiLPA terhadap Anggaran Pendapatan Dan Belaja Daerah (APBD) Pemerintah Kota Banjar dari tahun 2007 sampai dengan 2014 sebesar 13,03\%. Pada tahun 2007 SiLPA sebesar Rp. $67.980 .036 .836,00$ atau $16,96 \%$ dari Anggaran Pendapatan Dan Belanja Daerah (APBD) tahun yang sama sebesar Rp. 400.790.295.954,00 yang merupakan rasio terbesar SiLPA selama kurun waktu 2007 sampai dengan 2014. Pada tahun 2014 rasio Sisa Lebih Pembiayaan Anggaran (SiLPA) sebesar Rp. 82.880.966.092,00 atau 10,69\% terhadap Anggaran Pendapatan Dan
Belanja Daerah (APBD) tahun yang sama sebesar Rp. 775.655.011.235,00 yang merupakan rasio terkecil SiLPA selama kurun waktu 2007 sampai dengan 2014. Berdasarkan data tersebut menunjukkan bahwa Pemerintah Kota Banjar masih belum optimal untuk mengelola Sisa Lebih Pembiayaan Anggaran (SiLPA).

Penelitian ini ditujukan untuk mempelajari, mengetahui, dan menganalisis adalah untuk mempelajari, mengetahui, dan menganalisis pengaruh Pendapatan Asli Daerah (PAD), Dana Alokasi Umum (DAU) dan Sisa Lebih Pembiayaan Anggaran (SiLPA) terhadap Anggaran Belanja Modal pada Pemerintah Kota Banjar.

\section{METOOLOGI}

Dalam penelitian ini digunakan Metode yang digunakan dalam penelitian ini adalah ex post facto. Menurut Sugiyono (2010: 7) bahwa "Metode ex post facto merupakan suatu penelitian yang dilakukan untuk meneliti peristiwa yang telah terjadi dan kemudian mengurut ke belakang untuk mengetahui faktor-faktor yang dapat menimbulkan kejadian tersebut".

Desain/jenis penelitian yang akan digunakan dalam penyusunan tesis ini adalah desain penelitian kuantitatif. Yaitu desain yang dilakukan pada empirik tidak secara mendalam melainkan meluas, untuk memperoleh pengetahuan ilmiah yang bersifat abstarak, general dan universal (Rusidi dan Enas, 2011:27). Tempat/lokasi penelitian dilakukan di Dinas Pendapatan Pengelolaan Keuangan dan Aset Daerah Kota Banjar. Waktu penelitian adalah Oktober 2015 s.d Mei 2016.

Sumber data yang digunakan dalam penelitian ini adalah data sekunder, data sekunder yaitu data yang dikumpulkan oleh lembaga pengumpul data serta dipublikasikan pada masyarakat pengguna 
data (Sugiyono, 2010:150). Data berupa Pendapatan Asli Daerah (PAD), Dana Alokasi Umum (DAU), Sisa Lebih Pembiayaan Anggaran (SiLPA) dan Anggaran Belanja Modal yang diperoleh dari Dinas Pendapatan Pengelolaan Keuangan dan Aset Daerah Kota Banjar yang berpedoman kepada Peraturan Daerah Kota Banjar tentang Anggaran Pendapatan dan Belanja Daerah (APBD) Kota Banjar dari tahun 2007 sampai dengan 2014.

Adapun alat pengumpul data yang dipergunakan dalam penelitian ini, meliputi teknik-teknik sebagai berikut:

1) Studi Pustaka (Library Research)

2) Studi Lapangan (Field Research)

Teknik Analisis data yang digunakan dalam penelitian ini adalah:

\section{1) Statistik Deskriptif}

Penelitian ini menggunakan statistik Deskriptif, yang menginformasikan tentang nilai mininum, nilai maksimum, rata-rata (mean), dan nilai standar deviasi dari variabel-variabel independen dan dependen yang dijabarkan dalam bentuk statistik.

\section{2) Uji Asumsi Klasik}

Salah satu syarat yang menjadi dasar penggunaan regresi berganda adalah terpenuhinya semua asumsi klasik, agar hasil pengujian bersifat tidak bias dan efisien (Best Linear Unbiased Estimator/BLUE). Pengujian Asumsi Klasik dalam penelitian ini dilakukan dengan bantuan Program Statistik. Menurut Ghozali (2009) menyatakan asumsi klasik yang harus dipenuhi adalah:

\section{a. Berdistribusi normal;}

b. Non-multikolinearitas, artinya antara variabel independen dalam model regresi tidak memiliki korelasi atau hubungan secara sempurna ataupun mendekati sempurna; c. Homoskedasitas, artinya variance variable independen dari satu pengamatan ke pengamatan lain adalah konsisten atau sama; dan

d. Non-autokorelasi, artinya kesalahan pengganggu dalam model regresi tidak saling korelasi.

\section{3) Analisis Statistik Induktif (Inferensial)}

Analisis yang digunakan untuk menguji pengaruh variabel independen terhadap variabel dependen adalah analisis jalur (Analysis Path) yaitu untuk menganalisis hubungan sebab akibat yang terjadi antara variabel bebas dan terikat baik secara langsung maupun tidak langsung

\section{HASIL \& PEMBAHASAN}

\section{1) Hasil Penelitian}

Berikut ini adalah hasil rekapitulasi pengaruh Pendapatan Asli Daerah (PAD) $\left(\mathrm{X}_{1}\right)$, Alokasi Umum (DAU) $\left(\mathrm{X}_{2}\right)$ dan Sisa Lebih Pembiayaan Anggaran (SiLPA) $\left(\mathrm{X}_{3}\right)$ terhadap Anggaran Belanja Modal (Y) menggunakan program SPSS, penulis sajikan dalam tabel 1 sebagai berikut:

Tabel 1. Pengaruh Pendapatan Asli Daerah (PAD) $\left(\mathrm{X}_{1}\right)$, Dana Alokasi Umum (DAU) $\left(\mathrm{X}_{2}\right)$ Dan Sisa Lebih Pembiayaan Anggaran (SiLPA) $\left(\mathrm{X}_{3}\right)$ Terhadap Anggaran Belanja Modal (Y)

\begin{tabular}{ccccccc}
\hline $\begin{array}{c}\text { Variabe } \\
\mathbf{l}\end{array}$ & $\mathbf{R}$ & $\begin{array}{c}\mathbf{R} \\
\text { Squa } \\
\text { re }\end{array}$ & $\begin{array}{c}\text { Bet } \\
\mathbf{a}\end{array}$ & $\mathbf{t}$ & $\mathbf{F}$ & Sig \\
\hline $\mathbf{X}_{\mathbf{1}}-\mathbf{Y}$ & 0,64 & 0,416 & 0,05 & 3,40 & - & 0,01 \\
& 5 & & 5 & 9 & & 4 \\
$\mathbf{X}_{\mathbf{2}}-\mathbf{Y}$ & 0,83 & 0,703 & 0,34 & 3,76 & & 0,00 \\
& 8 & & 2 & 8 & & 9 \\
$\mathbf{X}_{\mathbf{3}}-\mathbf{Y}$ & 0,90 & 0,814 & 0,51 & 5,11 & & 0,00 \\
& 2 & & 4 & 7 & & 2 \\
$\mathbf{X}_{\mathbf{1}} \mathbf{X}_{\mathbf{2}} \mathbf{X}_{\mathbf{3}}-$ & 0,94 & 0,888 & 0,91 & - & 10,60 & 0,02 \\
$\mathbf{Y}$ & 3 & & 1 & & 5 & 2 \\
\hline
\end{tabular}


journal of managementReview

ISSN-P : 2580-4138 ISSN-E 2579-812X http://jurnal.unigal.ac.id/index.php/managementreview Volume 1 Number 1 Page (13-23)

A. Pengaruh Pendapatan Asli Daerah (PAD) $\left(\mathbf{X}_{1}\right)$ Terhadap Anggaran Belanja Modal (Y).

Berdasarkan Tabel 1 diketahui bahwa hubungan antara variabel Pendapatan Asli Daerah (PAD) $\left(\mathrm{X}_{1}\right)$ terhadap Anggaran Belanja Modal (Y) yang dihitung dengan Koefisien Korelasi adalah 0,645. Berdasarkan angka tersebut menunjukkan bahwa terdapat hubungan yang tinggi antara variabel $\left(\mathrm{X}_{1}\right)$ dengan $(\mathrm{Y})$ karena berada pada interval 0,61-0,80. Untuk menyatakan besar kecilnya kontribusi (sumbangan) variabel $\left(\mathrm{X}_{1}\right)$ terhadap $(\mathrm{Y})$, dapat dilihat bahwa koefisien determinan sebesar 0,416. Artinya anggaran belanja modal dipengaruhi oleh Pendapatan Asli Daerah (PAD) sebesar 41,6\%, sedangkan sisanya sebesar $58,4 \%$ dipengaruhi faktor lain yang tidak diteliti. Dengan demikian dapat disimpulkan bahwa terdapat Pengaruh Positif antara variabel Pendapatan Asli Daerah (PAD) ( $\left.\mathrm{X}_{1}\right)$ terhadap Anggaran Belanja Modal (Y).

Berdasarkan hasil analisis regresi linier $(\mathrm{Y}=$ $a+b_{1} X_{1}$ ) pada analisa pengaruh Pendapatan Asli Daerah (PAD) terhadap Anggaran Belanja Modal diperoleh nilai $\mathrm{a}=1 \mathrm{E}+011$ dan nilai $b$ sebesar 1,283 . berdasarkan nilai tersebut, diperoleh persamaan regresi yang menggambarkan skor ramalan Anggaran Belanja Modal berdasarkan Pendapatan Asli Daerah (PAD) sebagai berikut: $\mathrm{Y}=$ $(1 \mathrm{E}+011)+1,283 \mathrm{X}_{1}$. Artinya jika $\mathrm{X}_{1}$ dinaikkan 1\% maka Y naik 1,283.

Berdasarkan Tabel 1. tersebut pun dapat dilihat bahwa nilai $\mathrm{t}$ hitung adalah sebesar 3,409 dengan signifikasi $0,014<0,05$. Dan nilai $\mathrm{t}_{\text {tabel }}$ dengan $\mathrm{df}=8-2=6$ pada tingkat signifikasi 5\% adalah sebesar 2,446. Dengan demikian, karena $t_{\text {hitung }} 3,409>t_{\text {tabel }}$ 2,446, dapat disimpulkan bahwa Ho ditolak. Artinya, terdapat pengaruh positif antara variabel Pendapatan Asli Daerah (PAD) $\left(\mathrm{X}_{1}\right)$ terhadap Anggaran Belanja Modal (Y).

\section{B. Pengaruh Dana Alokasi Umum (DAU) $\left(\mathbf{X}_{2}\right)$ Terhadap Anggaran Belanja Modal (Y).}

Berdasarkan Tabel 1 diketahui bahwa hubungan antara variabel Dana Alokasi Umum (DAU) $\left(\mathrm{X}_{2}\right)$ dengan Anggaran Belanja Modal (Y) yang dihitung dengan Koefisien Korelasi adalah 0,838. Berdasarkan angka tersebut menunjukkan bahwa terdapat Hubungan Yang Sangat Tinggi antara variabel $\left(\mathrm{X}_{2}\right)$ dengan $(\mathrm{Y})$ karena berada pada interval 0,81-1,00. Untuk menyatakan besar kecilnya kontribusi (sumbangan) variabel $\left(\mathrm{X}_{2}\right)$ terhadap (Y), dapat dilihat bahwa Koefisien Determinan sebesar 0,703. Artinya Anggaran Belanja Modal dipengaruhi oleh Dana Alokasi Umum (DAU) sebesar $70,3 \%$, sedangkan sisanya sebesar $29,7 \%$ dipengaruhi faktor-faktor lain yang tidak diteliti. Dengan demikian dapat disimpulkan bahwa terdapat Pengaruh Positif antara variabel Dana Alokasi Umum (DAU) $\left(\mathrm{X}_{2}\right)$ terhadap Anggaran Belanja Modal (Y).

Berdasarkan hasil Analisis Regresi Linier $\left(\mathrm{Y}=\mathrm{a}+\mathrm{b}_{2} \mathrm{X}_{2}\right.$ ) pada analisa pengaruh Dana Alokasi Umum (DAU) terhadap Anggaran Belanja Modal diperoleh nilai $\mathrm{a}=5 \mathrm{E}+010$ dan nilai b sebesar 0,834 . berdasarkan nilai tersebut, diperoleh persamaan regresi yang menggambarkan skor ramalan Anggaran Belanja Modal berdasarkan Dana Alokasi Umum (DAU) sebagai berikut: $\mathrm{Y}=$ $(5 \mathrm{E}+010)+0,834 \mathrm{X}_{2}$. Artinya jika $\mathrm{X}_{2}$ dinaikkan $1 \%$ maka Y naik 0,834 .

Berdasarkan Tabel 1 dapat dilihat bahwa nilai $t_{\text {hitung }}$ adalah sebesar 3,768 dengan tingkat signifikasi $0,009<0,05$. Dan nilai $\mathrm{t}$ tabel dengan $\mathrm{df}=8-2=6$ pada tingkat signifikasi 5\% adalah sebesar 2,446. Dengan demikian, karena $t_{\text {hitung }} 3,768>t_{\text {tabel }}$ 2,446, dapat disimpulkan bahwa Ho ditolak. Artinya, terdapat Pengaruh Positif antara variabel Dana Alokasi Umum (DAU) $\left(\mathrm{X}_{2}\right)$ terhadap Anggaran Belanja Modal (Y). 


\section{Pengaruh Sisa Lebih Pembiayaan Anggaran (SiLPA) $\left(\mathbf{X}_{3}\right)$ Terhadap Anggaran Belanja Modal (Y).}

Berdasarkan Tabel 1 diketahui bahwa hubungan antara variabel Sisa Lebih Pembiayaan Anggaran (SiLPA) $\left(\mathrm{X}_{3}\right)$ dengan Anggaran Belanja Modal (Y) yang dihitung dengan Koefisien Korelasi adalah sebesar 0,902. Berdasarkan angka tersebut menunjukkan bahwa terdapat Hubungan Yang Sangat Tinggi antara variabel $\left(\mathrm{X}_{3}\right)$ dengan (Y) karena berada pada interval 0,81-1,00. Untuk menyatakan besar kecilnya kontribusi (sumbangan) variabel $\left(\mathrm{X}_{3}\right)$ terhadap $(\mathrm{Y})$, dapat dilihat bahwa Koefisien Determinan sebesar 0,814. Artinya Anggaran Belanja Modal dipengaruhi oleh Sisa Lebih Pembiayaan Anggaran (SiLPA) sebesar 81,40\%, sedangkan sisanya sebesar $18,6 \%$ dipengaruhi faktor-faktor lain yang tidak diteliti. Dengan demikian dapat disimpulkan bahwa terdapat Pengaruh Positif antara variabel Sisa Lebih Pembiayaan Anggaran (SiLPA) $\left(\mathrm{X}_{3}\right)$ terhadap Anggaran Belanja Modal (Y).

Berdasarkan hasil Analisis Regresi Linier $\left(\mathrm{Y}=\mathrm{a}+\mathrm{b}_{3} \mathrm{X}_{3}\right.$ ) pada analisa pengaruh Sisa Lebih Pembiayaan Anggaran (SiLPA) terhadap Anggaran Belanja Modal diperoleh nilai $\mathrm{a}=2 \mathrm{E}+010$ dan nilai $\mathrm{b}$ sebesar 2,679. berdasarkan nilai tersebut, diperoleh persamaan regresi yang menggambarkan skor ramalan Anggaran Belanja Modal berdasarkan Sisa Lebih Pembiayaan Anggaran (SiLPA) sebagai berikut: $\mathrm{Y}=(2 \mathrm{E}+010)+2,679 \mathrm{X}_{3}$. Artinya jika $\mathrm{X}_{3}$ dinaikkan $1 \%$ maka $\mathrm{Y}$ naik 2,679.

Berdasarkan Tabel 1 dapat dilihat bahwa nilai $t_{\text {hitung }}$ adalah sebesar 5,117 dengan tingkat signifikasi $0,002<0,05$. Dan nilai $t$ tabel dengan $\mathrm{df}=8-2=6$ pada tingkat signifikasi $5 \%$ adalah sebesar 2,446. Dengan demikian, karena $t_{\text {hitung }} 5,117>t_{\text {tabel }}$ 2,446, dapat disimpulkan bahwa Ho ditolak. Artinya, terdapat Pengaruh Positif antara variabel Sisa Lebih Pembiayaan Anggaran (SiLPA) $\left(\mathrm{X}_{3}\right)$ terhadap Anggaran Belanja Modal (Y).

\section{Pengaruh Pendapatan Asli Daerah (PAD) $\left(\mathbf{X}_{1}\right)$, Dana Alokasi Umum (DAU) $\quad\left(\mathbf{X}_{2}\right)$ Dan Sisa Lebih Pembiayaan Anggaran (Silpa) $\left(\mathbf{X}_{3}\right)$ Terhadap Anggaran Belanja Modal (Y).}

Berdasarkan Tabel 1 diketahui bahwa hubungan antara variabel Pendapatan Asli Daerah (PAD) $\left(\mathrm{X}_{1}\right)$, Dana Alokasi Umum (DAU) $\left(\mathrm{X}_{2}\right)$ Dan Sisa Lebih Pembiayaan Anggaran (Silpa) $\left(\mathrm{X}_{3}\right)$ dengan Anggaran Belanja Modal (Y) yang dihitung dengan Koefisien Korelasi sebesar 0,943. Berdasarkan angka tersebut menunjukkan bahwa terdapat Hubungan Yang Sangat Tinggi antara variabel $\left(\mathrm{X}_{1}\right),\left(\mathrm{X}_{2}\right)$ dan $\left(\mathrm{X}_{3}\right)$ dengan (Y) karena berada pada interval 0,81-1,00. Untuk menyatakan besar kecilnya kontribusi (sumbangan) variabel $\left(\mathrm{X}_{1}\right),\left(\mathrm{X}_{2}\right)$ dan $\left(\mathrm{X}_{3}\right)$ terhadap $(\mathrm{Y})$, dapat dilihat bahwa Koefisien Determinan sebesar 0,888. Artinya Anggaran Belanja Modal dipengaruhi oleh Pendapatan Asli Daerah (PAD), Dana Alokasi Umum (DAU) Dan Sisa Lebih Pembiayaan Anggaran (Silpa) sebesar 88,80\%, sedangkan sisanya sebesar $11,20 \%$ dipengaruhi faktor-faktor lain yang tidak diteliti. Dengan demikian dapat disimpulkan bahwa terdapat Pengaruh Positif antara variabel Pendapatan Asli Daerah (PAD) $\left(\mathrm{X}_{1}\right)$, Dana Alokasi Umum (DAU) $\left(\mathrm{X}_{2}\right)$ Dan Sisa Lebih Pembiayaan Anggaran (SiLPA) $\left(\mathrm{X}_{3}\right)$ terhadap Anggaran Belanja Modal (Y).

Berdasarkan hasil Analisis Regresi Linier $\left(\mathrm{Y}=\mathrm{a}+\mathrm{b}_{1} \mathrm{X}_{1}+\mathrm{b}_{2} \mathrm{X}_{2}+\mathrm{b}_{3} \mathrm{X}_{3}\right)$ pada analisa Pendapatan Asli Daerah (PAD) $\left(\mathrm{X}_{1}\right)$, Dana Alokasi Umum (DAU) $\left(\mathrm{X}_{2}\right)$ Dan Sisa Lebih Pembiayaan Anggaran (SiLPA) $\left(\mathrm{X}_{3}\right)$ terhadap Anggaran Belanja Modal (Y) diperoleh nilai $\mathrm{a}=7 \mathrm{E}+010$ dan nilai $\mathrm{b}_{1}=$ 0,109 , nilai $b_{2}=0,439$, dan nilai $b_{3}=1,822$. 
Persamaan regresinya $\mathrm{Y}=(7 \mathrm{E}+010)+$ $0,109 X_{1}+0,439 X_{2}+1,822 X_{3}$. Artinya jika $\mathrm{X}_{1}, \mathrm{X}_{2}$ dan $\mathrm{X}_{3}$ dinaikkan $1 \%$ maka $\mathrm{Y}$ naik $0,109,0,439$, dan 1,822 .

Berdasarkan Tabel 1 dapat dilihat bahwa diperoleh $F_{\text {hitung }}$ sebesar 10,605 dengan tingkat signifikasi $0,022<0,05$. Dan nilai $\mathrm{F}_{\text {tabel }}$ dengan $\mathrm{df}=8-2=6$ maka diperoleh $F_{\text {tabel }}$ 4,46. Dengan demikian karena $F_{\text {hitung }}$ $10,605>\mathrm{F}_{\text {tabel }} 4,46$, dapat disimpulkan bahwa ho ditolak. Artinya terdapat Pengaruh Positif antara Pendapatan Asli Daerah (PAD) $\left(\mathrm{X}_{1}\right)$, Dana Alokasi Umum (DAU) $\left(\mathrm{X}_{2}\right)$ Dan Sisa Lebih Pembiayaan Anggaran (Silpa) $\left(\mathrm{X}_{3}\right)$ terhadap Anggaran Belanja Modal (Y).

Berdasarkan data dari Tabel 1 dapat disusun matriks jalur, yaitu sebagai berikut:

$$
\begin{array}{lll}
\operatorname{\rho yx}_{1} & = & 0,055 \\
\operatorname{\rho yx}_{2} & = & 0,342 \\
\operatorname{\rho yx}_{3} & = & 0,514 \\
\operatorname{pyx}_{1} x_{2} x_{3} & = & 0,911
\end{array}
$$

Berdasarkan Beta tersebut, dapat dihitung koefisien jalur variabel lain diluar model yakni Pyé dengan rumus Pyé $=1-0,911=$ 0,089 .

Semua perolehan hasil perhitungan tersebut dapat digambarkan pada persamaan $\mathrm{Y}=$ $0,055 \mathrm{X}_{1}+0,342 \mathrm{X}_{2}+0,514 \mathrm{X}_{3}+0,089 \dot{\varepsilon}$ dan diagram jalurnya adalah sebagai berikut:

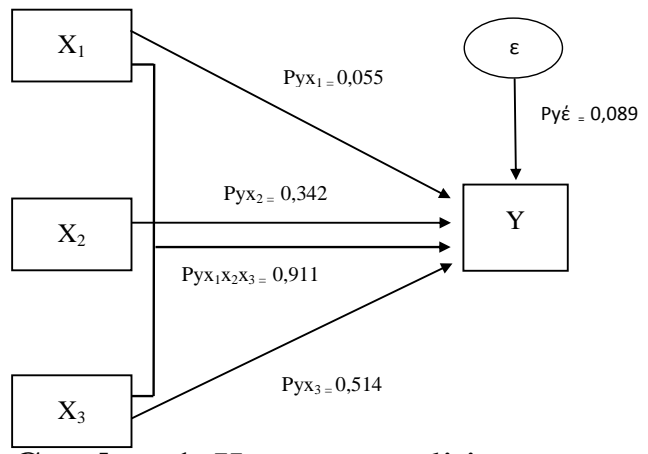

Gambar 1. Konsep penelitian

Keterangan:

$$
\begin{aligned}
\operatorname{pyx}_{1=0,055}= & \text { Koefisien Jalur pengaruh } \\
& \text { Pendapatan Asli Daerah } \\
& \text { (PAD) }\left(\mathrm{X}_{1}\right) \text { terhadap } \\
& \text { Anggaran Belanja Modal }(\mathrm{Y})
\end{aligned}
$$

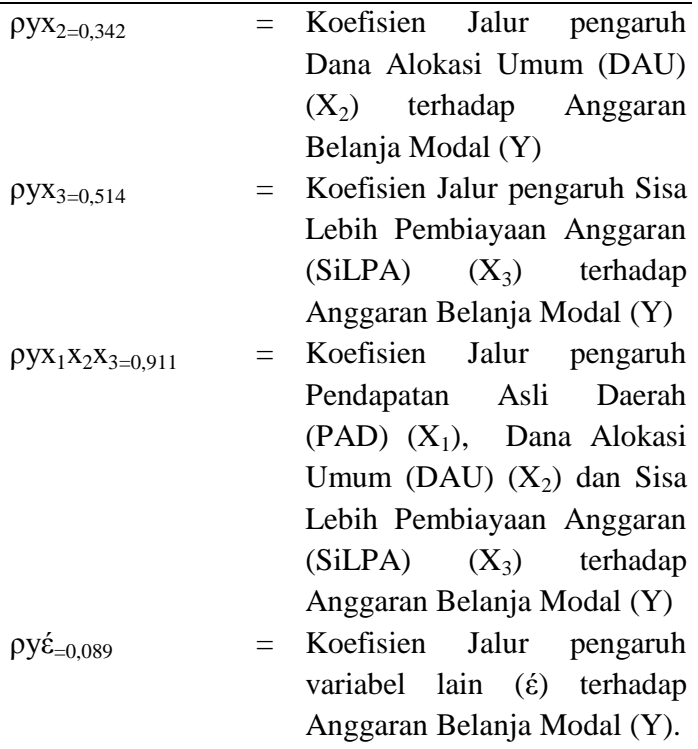

\section{2) Pembahasan}

A. Pendapatan Asli Daerah (PAD) $\left(\mathrm{X}_{1}\right)$ terhadap Anggaran Belanja Modal (Y).

Berdasarkan hasil analisis diperoleh kenyataan bahwa terdapat hubungan yang tinggi antara Pendapatan Asli Daerah (PAD) $\left(\mathrm{X}_{1}\right)$ terhadap Anggaran Belanja Modal (Y).

Hasil penelitian ini sejalan dengan pendapat Mahmudi (2010:18) yang menyatakan bahwa:

Peningkatan kemandirian daerah sangat erat kaitannya dengan kemampuan daerah dalam mengelola Pendapatan Asli Daerah (PAD). Semakin tinggi kemampuan daerah dalam menghasilkan PAD, maka semakin besar pula diskresi daerah untuk menggunakan PAD tersebut sesuai aspirasi, kebutuhan, dan prioritas pembangunan daerah.

Manajemen Pendapatan erat kaitannya dengan kemampuan Pemerintah Daerah untuk mengelola potensi fiskal. dengan menggali semua potensi yang dimiliki daerah dengan tetap memperhatikan implikasinya bagi masyarakat, artinya jangan sampai upaya meningkatkan Pendapatan Asli Daerah (PAD) justru 
menjadi beban yang memberatkan masyarakat. Semakin Tinggi Pendapatan Asli Daerah (PAD) Maka Semakin Tinggi Pula Anggaran Belanja Modal.

\section{B. Pengaruh Dana Alokasi Umum (DAU) $\left(\mathrm{X}_{2}\right)$ terhadap Anggaran Belanja Modal (Y).}

Berdasarkan hasil analisis diperoleh kenyataan bahwa terdapat hubungan yang sangat tinggi antara variabel Dana Alokasi Umum (DAU) $\left(\mathrm{X}_{2}\right)$ dengan Anggaran Belanja Modal (Y).

Hasil penelitian ini sejalan dengan pendapat Sumarsono (2010:119) menyatakan bahwa "Dana Alokasi Umum agar diprioritaskan penggunaannya untuk mendanai gaji dan tunjangan pegawai, kesejahteraan pegawai, kegiatan operasi dan pemeliharaan sarta pembangunan fisik sarana dan prasarana dalam rangka peningkatan pelayanan dasar dan pelayana umum yang dibutuhkan masyarakat". Dan Darwanto Dan Yustikasari (2007) menyatakan bahwa:

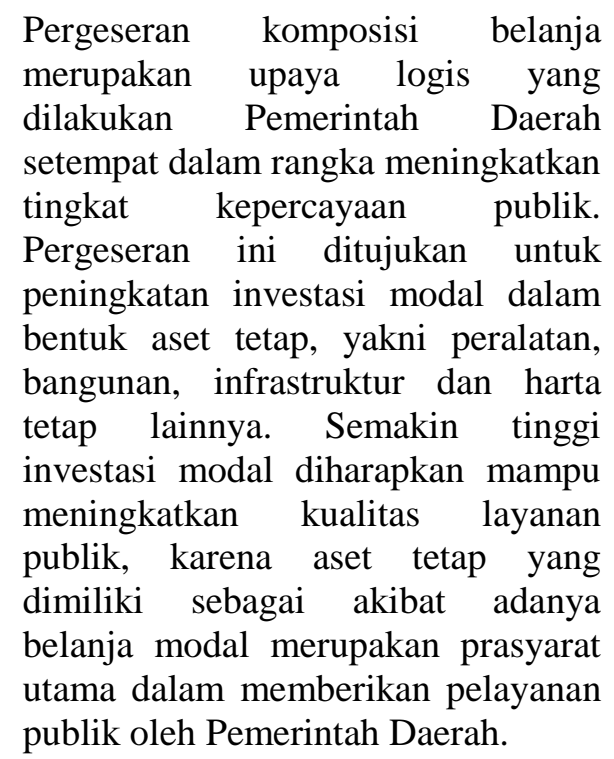

Dana Alokasi Umum (DAU) yang bersifat block grant akan memberikan keleluasaan bagi Pemerintah Daerah untuk mengoptimalkannya dalam bentuk alokasi belanja modal. Berdasarkan paparan tersebut semakin tinggi Dana Alokasi Umum semakin tinggi pula anggaran belanja modal.

\section{Pengaruh Sisa Lebih Pembiayaan Anggaran (SiLPA) $\left(\mathrm{X}_{3}\right)$ terhadap Anggaran Belanja Modal (Y).}

Berdasarkan hasil analisis diperoleh kenyataan bahwa terdapat hubungan yang sangat tinggi antara variabel Sisa Lebih Pembiayaan Anggaran (SiLPA) $\left(\mathrm{X}_{3}\right)$ dengan Anggaran Belanja Modal (Y).

Hasil penelitian ini sejalan dengan pendapat Mahmudi (2010:4) menyatakan bahwa "Apabila terjadi sisa anggaran pada akhir periode maka sisa anggaran tersebut tidak akan lagi hangus, akan tetapi dapat digunakan sebagai sumber pembiayaan untuk tahun anggaran berikutnya yang masuk dalam kategori Sisa Lebih Pembiayaan Anggaran (SiLPA)".

Dengan tambahan penerimaan pembiayaan dari Sisa Lebih Pembiayaan Anggaran (SiLPA) maka Pemerintah Daerah memiliki kecukupan dana dalam rangka penyelenggaran pemerintahan daerah dan meningkatkan pelayanan publik dengan mengalokasikan dana yang optimal untuk anggaran belanja modal. Sisa Lebih Pembiayaan Anggaran (SiLPA) yang berasal dari peningkatan kinerja pendapatan dan efisiensi belanja daerah, merupakan dana segar yang dapat digunakan oleh Pemerintah Daerah untuk meningkatkan Anggaran Belanja Modal dalam upaya meningkatkan pelayanan publik. Semakin tinggi Sisa Lebih Pembiayaan Anggaran (SiLPA) maka semakin tinggi pula anggaran belanja modal.

D. Pengaruh Pendapatan Asli Daerah (PAD) $\left(\mathbf{X}_{1}\right)$, Dana Alokasi Umum (DAU) $\left(\mathbf{X}_{2}\right)$ Dan Sisa Lebih Pembiayaan Anggaran (Silpa) $\left(\mathbf{X}_{3}\right)$ Terhadap Anggaran Belanja Modal (Y).

Berdasarkan hasil analisis diperoleh kenyataan bahwa terdapat hubungan yang sangat tinggi antara variabel Pendapatan 
Asli Daerah (PAD) $\left(\mathrm{X}_{1}\right)$, Dana Alokasi Umum (DAU) $\left(\mathrm{X}_{2}\right)$ Dan Sisa Lebih Pembiayaan Anggaran (Silpa) $\left(\mathrm{X}_{3}\right)$ dengan Anggaran Belanja Modal (Y).

Hasil penelitian ini sejalan dengan pendapat Halim (2014:226) menyatakan bahwa:

Berdasarkan agency theory di sektor publik, kinerja pemerintah dinilai melalui anggaran yang dibuatnya, sehingga diharapkan pengeluaran pemerintah yang menyentuh pada fungsi pelayanan kepada masyarakat, yang berwujud dalam belanja modal, harus mendapatkan porsi yang relatif besar.

Keberpihakkan Pemerintah Daerah terhadap peningkatan pelayanan publik dengan menyediakan sarana dan prasarana yang memadai melalui pengalokasian dana yang optimal untuk anggaran belanja modal akan kurang optimal jika tidak diimbangi dengan Kemampuan Keuangan Daerah (Fiscal Capacity). Upaya untuk meningkatkan Kamampuan Fiskal Daerah (fiscal capacity) dapat dilakukan dengan cara mengelola dan meningkatkan Pendapatan Asli Daerah (PAD), mengoptimalkan pendapatan dari Dana Perimbangan Atau Dana Transfer Dari Pemerintah Pusat, salah satunya adalah Dana Alokasi Umum (DAU) dan memanfaatkan dengan optimal Sisa Lebih Pembiayaan Anggaran (SiLPA) tahun sebelumnya untuk menutup kesenjangan fiskal (fiscal gap).

Berdasarkan paparan diatas maka Semakin tinggi Pendapatan Asli Daerah (PAD), Dana Alokasi Umum (DAU) dan Sisa Lebih Pembiayaan Anggaran (SiLPA), maka semakin tinggi pula anggaran belanja modal.

\section{SIMPULAN}

Berdasarkan pembahasan dari hasil penelitian maka dapat disimpulkan beberapa hal sebagai berikut:
1. Berdasarkan data yang diperoleh bahwa Pendapatan Asli Daerah (PAD) Pemerintah Kota Banjar pendapatan tertinggi terjadi pada tahun 2014. Artinya Pendapatan Asli Daerah (PAD) sangat dipengaruhi oleh kenaikan pendapatan pajak daerah, hasil retribusi daerah, hasil pengelolaan kekayaan daerah yang dipisahkan dan lain-lain pendapatan asli daerah yang sah pada tahun 2014 . Pendapatan Asli Daerah (PAD) berpengaruh terhadap anggaran belanja modal. Artinya jika Pendapatan Asli Daerah (PAD) ditingkatkan, maka anggaran belanja modal akan meningkat pula. Dengan demikian hipotesis 1 teruji kebenarannya atau signifikan karena $\mathrm{t}_{\text {hitung }}>\mathrm{t}_{\text {tabel }}$ dengan $P$ value 0,014 atau dibawah 0,05 .

2. Berdasarkan data yang diperoleh bahwa Dana Alokasi Umum (DAU) Pemerintah Kota Banjar tertinggi terjadi pada tahun 2014. Artinya Dana Alokasi Umum (DAU) sangat dipengaruhi oleh kenaikan Alokasi dasar yang dihitung berdasarkan jumlah Gaji Pegawai Negeri Sipil Daerah dan Celah fiskal yang merupakan selisih dari Kebutuhan Fiskal Kapasitas Fiskal pada tahun 2014. Dana Alokasi Umum (DAU) berpengaruh terhadap anggaran belanja modal. Artinya jika Dana Alokasi Umum (DAU) ditingkatkan, maka anggaran belanja modal akan meningkat pula. Dengan demikian hipotesis 2 teruji kebenarannya atau signifikan karena $\mathrm{t}_{\text {hitung }}>\mathrm{t}_{\text {tabel }}$ dengan $P$ value 0,009 atau dibawah 0,05 .

3. Berdasarkan data yang diperoleh bahwa Sisa Lebih Pembiayaan Anggaran (SiLPA) Pemerintah Kota Banjar pendapatan tertinggi terjadi pada tahun 2013. Artinya Sisa Lebih Pembiayaan Anggaran (SiLPA) sangat dipengaruhi oleh kenaikan kinerja 
pendapatan daerah dan tingkat belanja yang dilakukan oleh Pemerintah Daerah pada tahun 2013. Sisa Lebih Pembiayaan Anggaran (SiLPA) berpengaruh terhadap anggaran belanja modal. Artinya jika Sisa Lebih Pembiayaan Anggaran (SiLPA) ditingkatkan, maka anggaran belanja modal akan meningkat pula. Dengan demikian hipotesis 3 teruji kebenarannya atau signifikan karena $\mathrm{t}_{\text {hitung }}>\mathrm{t}_{\text {tabel }}$ dengan $P$-value 0,002 atau dibawah 0,05 .

4. Berdasarkan data yang diperoleh bahwa Anggaran Belanja Modal Pemerintah Kota Banjar tertinggi terjadi pada tahun 2013. Artinya Anggaran Belanja Modal sangat dipengaruhi oleh kenaikan Belanja Modal Tanah, Belanja modal peralatan dan mesin, Belanja modal gedung dan bangunan, Belanja modal jalan, jaringan dan irigasi; dan Belanja modal aset tetap lainnya pada tahun 2013. Pendapatan Asli Daerah (PAD), Dana Alokasi Umum (DAU) dan Sisa Lebih Pembiayaan Anggaran (SiLPA) berpengaruh terhadap anggaran belanja modal. Artinya jika Pendapatan Asli Daerah (PAD), Dana Alokasi Umum (DAU) dan Sisa Lebih Pembiayaan Anggaran (SiLPA) ditingkatkan, maka anggaran belanja modal akan meningkat pula. Dengan demikian hipotesis 4 teruji kebenarannya atau signifikan karena $\mathrm{F}_{\text {hitung }}>\mathrm{F}_{\text {tabel }}$ dengan $P$-value 0,022 atau dibawah 0,05

\section{DAFTAR PUSTAKA}

Adisasmita, Rahardjo. (2011), Pengelolaan Pendapatan dan Anggaran Daerah, Yogyakarta: Graha Ilmu.

Anggarini, Yunita dan Puranto, Hendra. (2010), Anggaran Berbasis Kinerja (Penyusunan APBD Secara Komprehensif), Yogyakarta: UPP STIM YKPN.
Aprizay, Darwanis dan Arpan. (2014), Pengaruh Pendapatan Asli Daerah, Dana Perimbangan Dan Sisa Lebih Pembiayaan Anggaran Terhadap Pengalokasian Belanja Modal Pada Kabupaten/Kota Di Provinsi Aceh, Jurnal akuntansi, Aceh: Pascasarjana Universitas Syiah Kuala

Bastian, Indra. (2006), Akuntansi Yayasan dan Sektor Publik, Jakarta: Erlangga.

Chabib, Soleh dan Rochmansjah, Heru. (2010), Pengelolaan Keuangan dan Aset Daerah, Bandung: Fokusmedia.

Darwanto dan Yulia Yustikasari. (2007), Pengaruh Pertumbuhan Ekonomi, Pendapatan Asli Daerah, Alokasi Umum terhadap Pengalokasian Belanja Modal. Simposium Akuntansi X. Makasar: Unhas.

Fakultas Ekonomi UGM. (2006), Runtuhnya Sistem Manajemen Keuangan Daerah, Yogyakarta: BPFE.

Ghozali, Imam. (2005), Analisis Program SPSS, Semarang: Undip.

Halim, Abdul. (2014), Manajemen Keuangan Sektor Publik (Anggaran Pendapatan dan Belanja Negara/Daerah), Jakarta: Salemba Empat.

Halim, Abdul dan Iqbal, Muhamad, (2012), Pengelolaan Keuangan Daerah, Seri Bunga Rampai Manajemen Keuangan Daerah, (Edisi Ketiga), Yogyakarta: UPP STIM YKPN.

Mahmudi. (2010), Akuntansi Sektor Publik, Yogyakarta: Andi.

Mahmudi. (2010), Manajemen Keuangan Daerah, Jakarta: Erlangga.

Mardiasmo. (2002), Otonomi dan Manajemen Keuangan Daerah, Yogyakarta: Andi.

Nugroho. (2005), Uji Asumsi Klasik dalam Penelitian Kuantitatif, Bandung: Pustaka.

Oktiniatmaja, R. (2009), Hubungan Pendapatan Asli Daerah, Dana Alokasi Umum, dan Dana Alokasi Khusus atas Belanja Modal Pada Pemerintah Daerah Kabupaten Tolitoli Provinsi Sulawesi Tengah. 
journal of managementReview

ISSN-P : 2580-4138 ISSN-E 2579-812X http://jurnal.unigal.ac.id/index.php/managementreview

Volume 1 Number 1 Page (13-23)

Jakarta: Prosiding Jurnal

Accountability.

Sugiyono. (2010), Metode Penelitian Administrasi, Bandung: Alfabeta.

Sumarsono, Sonny. (2010), Manajemen Keuangan Pemerintah, Yogyakarta: Graha Ilmu.

Surakhmad, Winarno. (1990), Pengantar Penelitian-penilitian Ilmiah, Bandung: Tarsito.

Rusidi dan Enas. (2010), Metode Penelitian (Elaborasi Pedoman Penulisan Skripsi, Tesis dan Disertasi, Bandung: Dewa Ruchi. ., Undang-undang Nomor 17 Tahun 2003 tentang Keuangan Negara. .,Undang-undang Nomor 33 Tahun 2004 tentang Antara Pemerintah Pusat Dengan Pemerintah Daerah. .Undang-Undang Nomor 28 tahun 2009 tentang Pajak Daerah Dan Retribusi Daerah. .,Undang-undang Nomor 23 Tahun 2014 tentang Pemerintah Daerah. .,Peraturan Pemerintah Nomor 58 Tahun 2005 tentang Pengelolaan Keuangan Daerah. .,Peraturan Pemerintah Nomor 71 Tahun 2010 tentang Standar Akuntansi Pemerintah.

,Permendagri Nomor 21 Tahun 2011 tentang Perubahan Kedua AtasPermendagri Nomor 13 Tahun 2006 tentang Pedoman Pengelolaan Keuangan Daerah. 
journal of managementReview

ISSN-P : 2580-4138 ISSN-E 2579-812X http://jurnal.unigal.ac.id/index.php/managementreview Volume 1 Number 1 Page (13-23) 